\title{
Antimitochindrial and antinuclear antibodies in primary biliary cholangitis
}

\author{
Dana Saipiyeva $^{1}$, Manarbek Askarov ${ }^{2}$, Turlybek Tuganbekov ${ }^{1}$, Kulsara Rustemova ${ }^{1}$, Vladimir Grigorevsky ${ }^{1}$, \\ Gulmira Dossatayeva ${ }^{3}$, Nina Tostanovskaya ${ }^{3}$
}

${ }^{1}$ No2 Surgical Diseases Department, Astana Medical University, Nur-Sultan city, Republic of Kazakhstan ${ }^{2}$ Cellular Technologies and Transplantation Center, National Scientific Medical Center, Nur-Sultan city, Republic of Kazakhstan

${ }^{3}$ Therapy and Cellular Technologies Department, National Scientific Medical Center, Nur-Sultan city, Republic of Kazakhstan

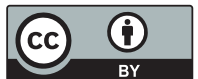

This work is licensed under a Creative Commons Attribution 4.0 International License

Received: 2019-04-26

Accepted: 2019-06-13

UDC: 616-097:616.36-004.7

J Clin Med Kaz 2019;2(52):16-22

Corresponding Author: Dana Saipiyeva, $\mathrm{PhD}$ student, No2 Department of Surgical Diseases, Astana Medical University, Nur-Sultan, Republic of Kazakhstan.

Tel: : +7 7070311834

E-mail: ualikd@mail.ru

\section{Abstract}

In this work we reviewed the key antimitochondrial and antinuclear antibodies in primary biliary cholangitis - an autoimmune cholestatic disorder with destruction of intralobular biliary ductules. Since the discovery of antibodies to PDC-E2 component of cholangiocyte mitochondrial membrane, more than 60 antimitochindrial and antinuclear antibodies against various cellular components of cholangiocytes have been described to date, which have primary diagnostic and clinical value in identifying the disease progression and prognosis.

Keywords: cholestasis, PDC-E2, antinuclear antibodies, cholangiocytes, autoimmune hepatic disorder

\section{БИЛИАРЛЫ ХОЛАНГИТ КЕЗІНДЕГІ АНТИМИТОХОНДРИАЛДЫ ЖӘНЕ АНТИЯДЕРЛІ АНТИДЕНЕ}

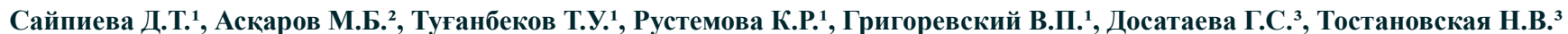

${ }^{1} № 2$ Хирургиялық аурулар кафедрасы, Астана медициналық университеті, Нұр-Сұлтан қаласы, Қазақстан Республикасы

²Жасушалы технологиялар және трансплантаттау орталығы, Ұлттық ғылыми медициналық орталық, Нұр-Сұлтан қаласы, Қазақстан Республикасы

${ }^{3}$ Терапия және жасушалық технологиялар бөлімі, Ұлттық ғылыми медициналық орталық, Нұр-Сұлтан қаласы, Қазақстан Республикасы

\section{ТҰЖЫРЫМДАМА}

Мақалада негізінен билиарлы холангит кезіндегі антимитохондриальды және антинуклеарлы антиденелер жөнінде талқыланады, сонымен қатар ішектің өт қабығының бұзылуы мен аутоиммунды холестатикалық бұзылыс туралы айтылған. Митохондриялы холангиоцит мембранасының PDC-E2 антигеніне қарсы антиденелер табылғандықтан, аурудың удеуін және болжамын анықтау үшін бугінгі таңда 60тан астам антимитохиндриалды және антинуклеарлы антиденелер сипатталған. Мұның диагностикалық және клиникалық құндылығы бар.

Негізгі сөздер: холестаз, PDC-E2, антинуклеарлы антиденелер, холангиоциттер, бауырдың аутоиммунды зақымдануы

АНТИМИТОХОНДРИАЛЬНЫЕ И АНТИНУКЛЕАРНЫЕ АНТИТЕЛА ПРИ ПЕРВИЧНОМ БИЛИАРНОМ ХОЛАНГИТЕ Сайпиева Д.Т. ${ }^{1}$, Аскаров М.Б. ${ }^{2}$, Туганбеков Т.У. ${ }^{1}$, Рустемова К.Р. ${ }^{1}$, Григоревский В.П. ${ }^{1}$, Досатаева Г.С. ${ }^{3}$, Тостановская Н.В. $^{3}$

'Кафедра хирургических болезней №2, Медицинский университет Астана, город Нур-Султан, Республика Казахстан

${ }^{2} Ц$ центр клеточных технологий и трансплантации, Национальный научный медицинский центр, город Нур-Султан, Республика Казахстан

${ }^{3}$ Отдел терапии и клеточных технологий, Национальный научный медицинский центр, город Нур-Султан, Республика Казахстан

\section{PEЗЮME}

В статье рассмотрены ключевые антимитохондриальные и антиядерные антитела при первичном билиарном холангите - аутоиммунном холестатическом расстройстве с разрушением внутридольковых желчных протоков. С момента открытия антител против антигена РDC-E2 митохондриальной мембраны холангиоцитов на сегодняшний день было описано более 60 антимитохиндриальных и антиядерных антител против различных клеточных структур холангиоцитов, которые имеют первичную диагностическую и клиническую ценность для выявления прогрессирования и прогноза заболевания.

ключевые слова: холестаз, PDC-E2, антинуклеарные антитела, холангиоциты, аутоиммунное поражение печени 


\section{Введение}

Первичный билиарный холангит (ПБХ) - хроническое аутоиммунное заболевание печени, поражающее преимущественно женское население в возрасте старше 40 лет и приводящее к ранней потере трудоспособности и качества жизни. Ключевым моментом в этиопатогенезе заболевания является появление в крови больных ПБХ аутоантител к митохондриям и компонентам ядра клеток билиарного эпителия. К настоящему моменту выявлено около 60 антимитохондриальных (АМА) и антинуклеарных (АНА) антител. Данная статья описывает структуру и механизм действия наиболее распространенных аутоантител, выявляемых при ПБХ.

Первый случай длительной желтухи, не связанный с обструкцией крупных желчных протоков, был описан Addison и Gull в 1851г, они также дали ему название синдром Аддисона-Галла. В 1949 году Dauphinee и Sinclair назвали это состояние первичным билиарным циррозом - хроническое поражение печени, характеризующееся аутоиммуным воспалительным разрушением холангиоцитов, малых внутрипеченочных протоков с последующим холестазом и типичными клиническими симптомами в виде зуда, астении и желтухи. В 2014 году Европейская и Американская ассоциации по изучению печени предложили изменение этого названия на первичный билиарный холангит (ПБХ), поскольку предыдущий термин цирроз относится только к заболеванию конечной стадии, тогда как патологические изменения начинаются задолго до возникновения цирроза. Точная причина потери иммунной толерантности до сих пор не установлена, несмотря на многочисленные исследования и теории. Эпидемиология болезни постепенно увеличивается от 1,91 до 40,2 на 100000 жителей, при этом количество новых случаев составляет от 0,33 до 5,8 на 100000 жителей в год. Медианный возраст начала заболевания составляет 54,5 года (диапазон 2567). Соотношение между женщинами и мужчинами по последним международным данным составляет 10:1. Распространенность заболевания может достигать 1:700 среди женщин старше 40 лет. Наиболее распространенными жалобами являются астения, выраженность которой не коррелирует со стадией заболевания, зуд, анорексия и желтуха или гиперпигментация с увеличенной печенью и селезенкой, являющиеся основными клиническими признаками. До 20\% случаев бессимптомны [1].

ПБХ часто ассоциируется с другими аутоиммунными состояниями, такими как аутоиммунный хронический гепатит (перекрестный синдром), синдром Шегрена, аутоиммунный тиреоидит и некоторые другие. Доказано, что эпителиоциты желчных и слюнных протоков имеют один и тот же аутоантиген [2].

Урсодезоксихолевая кислота (УДХК), единственный препарат первой линии, одобренный международными сообществами, в дозе 13-15 мг/кг в день внутрь рекомендован для замедления прогрессирования заболевания. Примерно у $30 \%$ пациентов УДХК неэффективна [3]. В настоящее время единственным радикальным лечением для ПБХ остается ортотопическая трансплантация печени (ОТП). Несмотря на оптимистичные $83 \%$ выживаемости через год после ОТП, существуют ограничения для этого метода, такие как отсутствие донорства органов, отторжение трансплантата, потребность в пожизненной иммуносупрессии и, самое главное, рецидив фиброза в трансплантатах печени до 65\% через пять лет и 71\% через 10 лет после трансплантации с возвратом характерных аутоиммунных нарушений у 100\% больных. В некоторых исследованиях сообщается о развитии портального фиброза в течение года после трансплантации печени у $31 \%$ педиатрических больных [4].

Основным механизмом патогенеза ПБХ является появление более 60 аутоантител к ядерным компонентам, клеточным мембранам или липидным фракциям эпителиоцитов желчных протоков, причем антимитохондриальные и антинуклеарные антитела являются доминирующими маркерами, обнаруженными в $95 \%$ и почти в 50\% пациентов с ПБХ соответственно [5].

Антимитохондриальные антитела (АМА) против эпителиоцитов желчных протоков при ПБХ были впервые обнаружены в 1958 году, и описаны Уокер и др. в 1965 году с помощью непрямой иммунофлюоресценции субклеточных фракций, полученных из тканей, богатых митохондриями, таких как крысиная печень, почка, щитовидная железа человека, реагировавших на сыворотки пациентов с ПБХ. Считается, что они являются надежными предикторами развивающегося заболевания задолго до появления его клинических или лабораторных признаков. Внедрение в лабораторную практику иммуноферментного анализа (ИФА, enzyme-linked immunoabsorbent assay, ELISA) привело к заметному прогрессу в серодиагностике ПБХ, позволившим перевести 90\% АМА-отрицательных случаев в АМА-позитивные. В 2012 году было обнаружено еще 6 аутоантигенов [6]. Их можно найти также в слюне и желчи [7]

Патогенетическое значение АMA, а также связь с клиническим проявлением можно лучше понять благодаря знанию митохондриальных мишеней АМА и их ролей в метаболизме клеток. Митохондрии, согласно эндосимбиотической теории их происхождения, произошли от прокариотических клеток, захваченных эукариотами в процессе эволюции и ставших «электростанцией клетки», основным АТФ-генератором (Philip Siekevitz, 1957) [8]. Митохондрии имеют независимый ДНК и РНК-геном, организованный в одну кольцевую хромосому и кодирующий 37 протеинов клеточного дыхания. Они наследуются только по материнской линии. Митохондрии могут вытягиваться, сливаться и делиться бинарным делением, подобно бактериям, в ответ на энергетическую потребность клеток [9].

Ключевым компонентом, позволяющим выполнять функции клеточного дыхания и метаболизма, является митохондриальная мембрана, состоящая из двух слоев - наружного и внутреннего, являющихся ключевой локацией клеточного метаболизма (включая цикл Кребса), электронного транспорта и окислительного фосфорилирования. Наружная мембрана содержит порины - мембранные протеины, формирующие неспецифические поры и позволяют свободное проникновение большинства небольших метаболитов, в т.ч. пируват. Повреждение наружной мембраны вызывает утечку содержимого межмембранного пространства в цитозоль, что приводит к гибели клеток. Внутренняя митохондриальная мембрана, основная мишень АМА, наоборот, проницаема только для тех метаболитов, для которых она содержит специфические системы-носители. Сильный электрохимический градиент концентрации протонов существует только на внутренней митохондриальной мембране [10]. Она имеет 
многочисленные складки (кристы), увеличивающиеплощадь ее поверхности (в пять раз больше площади внешней мембраны) и, соответственно, способность генерировать аденозинтрифосфат (АТФ). Они также участвуют в клеточном метаболизме, дыхании, сигнале, росте, дифференцировке и апоптозе (запрограммированной гибели клеток). Клеточное дыхание опосредуется молекулами пирувата, продуцируемыми гликолизом и активно переносимыми через внутреннюю митохондриальную мембрану в матрицу. Существует 9 митохондриальных субфракций, реагирующих с АМА, классифицированных как М1-М9. Из них М2, M4, М8 и М9 являются мишенями для аутоантител, выявляемых при ПБХ. Остальные M1 (кардиолипин), M3, M5 и M6 (наружная мембрана митохондрий) и М7 (саркозиндегидрогеназа), не связаны с ПБХ $[11,12]$.

Комплекс пируватдегидрогеназы (PDC) является очень важным метаболическим энзимом и представляет собой комплекс из трех ферментов: пируватдегидрогеназы, дигидролипоат-ацетилтрансфераза и дигидролипоатдегидрогеназа. Их основная роль участие в процессе окислительного декарбоксилирования пирувата, в результате которого пируват превращается в ацетил-СоА (с выделением $\mathrm{CO} 2$ и $\mathrm{NADH}(\mathrm{H}+)$, используемый в цикле Кребса и клеточном дыхании, и в связывании гликолизного метаболического пути с циклом Кребса. Ключевая роль при этом принадлежит именно PDC. Пируватдегидрогеназа (ПДГ) относится к семейству 2-оксокислот дегидрогеназы, два других компонента которого - 2-оксоглутаратдегидрогеназа (2-oxo-glutarate dehydrogenase complex - OGDC) и дегидрогеназы альфа-кетокислот с разветвленной цепью (branched-chain 2-охоасid dehydrogenase complex - BCOADC). Эти структурно и функционально связанные комплексы, состоящие из трех ферментов каждый, являются воротами аэробного метаболизма клеток, полностью сохраненными в процессе эволюции всеми живыми организмами. Они имеют общуюструктуру с многочисленными копиями частей $\mathrm{E} 1$ (2-оксокислотдегидрогеназы) и $\mathrm{E} 3$ (дигидролипамидадегидрогеназы), связанных с ядром Е2 и Е3связывающего белка (Е3 binding protein, Е3ВР) (Таблица 1).
После его ядерного кодирования и посттрансляционного транспорта комплексная сборка происходит в митохондриях, где хвост липоевой кислоты присоединяется к цепям Е2 и Е3ВР. В целом механизм их действия в том, что эти три компонента передают субстраты от одного энзима другому, и продукт одного энзима является субстратом для следующего. Блок какого-либо звена этой цепи вызовет сбой всей реакции в целом. PDC регенерируется путем множественных восстановительных реакций [12].

M2 - комплексный антиген, который состоит из 5 детерминант, расположенных на внутренней митохондриальной мембране, являющихся ключевым звеном митохондриального дыхания:

1 - дигидролипоамид ацетилтрансфераза или энзим 2 (enzyme 2 - E2) компонент пируват-дегидрогеназного комплекса (PDC-E2);

2 - Е2 компонент дегидрогеназы разветвленных альфа-кетокислот (branched-chain 2 oxоacid dehydrogenase complex);

3 - Е2 - компонент 2 оксоглутаратдегидрогеназы (2-oxoglutarate dehydrogenase complex);

4 - Е1 - альфа-компонент ПДГ (PDC);

5 - Е3 - связывающий протеин (белок Х).

PDC-E2 является доминирующим компонентом митохондриального антигена, основной мишенью аутоиммунного ответа в РВС (у 95\% AMА-позитивных пациентов) и специфическим маркером только диагностики PBC, а не других АМА-связанных заболеваний, таких как сифилис (анти-М1), волчаночно-подобный синдром (анти-М3) или кардиомиопатии (анти-М7). Данный антиген был обнаружен в 1987 году Эриком Гершвином с применением сыворотки пациента ПБХ для скрининга экспрессии, когда был идентифицирован клон ДНК, кодирующий PDC-E2. Исследования показывают, что аутоиммунный сбой практически всегда сфокусирован на PDC-E2. Антитела к компонентам E2 OGDC и BCOADC встречаются примерно у 90\% и 50\% пациентов с РВС соответственно. Сродство доминирующей В-клетки внутри PDC-E2 опосредуется липоевой кислотой, связанной с

Таблица 1 Состав пируватдегидрогеназного комплекса

\begin{tabular}{|c|c|c|c|}
\hline № & Комплекс & Функции & Энзимный состав \\
\hline & Пируватдегидрогеназа (PDH) & $\begin{array}{l}\text { связывает гликолиз с циклом } \\
\text { лимонной кислоты (цикл } \\
\text { Кребса) }\end{array}$ & $\begin{array}{l}\text { E1p - пируватдекарбоксилаза (пируватдегидрогеназа (липоамид) } \\
\text { (E1а и Е1b декарбоксилаза) декарбоксилаза пируват с ТРP } \\
\text { (тиаминпирофосфат) в качестве кофактора } \\
\text { E2p - дигидролипоилацетилтрансфераза переносит ацетильную группу } \\
\text { от Е1 к коферменту А (СоA) } \\
\text { E3p - дигидролипоилдегидрогеназа. Регенерация дисульфида E2 } \\
\text { окислением липоевой кислоты } \\
\text { E3BP - (белок X) - цепляет E3 к ядру E2 комплекса PDH }\end{array}$ \\
\hline & $\begin{array}{l}\text { 2-оксоглутаратдегидрогеназа } \\
\text { (20GDH) }\end{array}$ & в составе цикла Кребса: & $\begin{array}{l}\text { Е1о -2-оксоглутарат декарбоксилаза - декарбоксилаты } \alpha \text {-кетоглутарата } \\
\text { с ТРР в качестве кофактора } \\
\text { Е2о - дигидролипоилсукцинилтрансфераза - переносит сукцинильную } \\
\text { группу от Е2 к СоA } \\
\text { ЕЗо - дигидролипоилдегидрогеназа - регенерация дисульфида E2 } \\
\text { окислением липоевой кислоты }\end{array}$ \\
\hline & $\begin{array}{l}\text { Комплекс оксокислотной } \\
\text { дегидрогеназы (ODHC) } \\
\text { аминокислот } \\
\text { с разветвленной цепью }\end{array}$ & $\begin{array}{l}\text { катализирует необратимую } \\
\text { стадию катаболизма } \\
\text { незаменимых аминокислот с } \\
\text { разветвленной цепью:лейцин, } \\
\text { изолейцин и валин }\end{array}$ & $\begin{array}{l}\text { состоит из нескольких копий трех функционально эквивалентных } \\
\text { субъединичных ферментов. } \\
\text { Е1а декарбоксилаза - декарбоксилаты } \alpha \text {-кетокислот с ТФП } \\
\text { (тиаминпирофосфат) в качестве кофактора } \\
\text { Е1b - получен из лейцина, изолейцина и валина с ТРР в качестве } \\
\text { кофактора } \\
\text { Е2р - ацетилтрансфераза - переносит ацильную группу от Е1 к СоА } \\
\text { ЕЗо - дигидролипоилдегидрогеназа - регенерация дисульфида Е2 } \\
\text { окислением липоевой кислоты. }\end{array}$ \\
\hline
\end{tabular}


ее внутренним липоиловым домейном, и усиливающей связывание антиген-антитело [13].

Позже в наружной митохондриальной мембране были идентифицированы два других антитела: анти-М4 и анти-М8, отличающиеся своей чувствительностью к трипсину. М4 изначально был обнаружен в сыворотках холестатических пациентов с использованием теста фиксации комплемента, нечувствительного к трипсину. Он расположен во внешней мембране и в настоящее время обнаруживается у пациентов с хроническим гепатитом и ПБХ. Ключевыми компонентами являются субъединица PDC-E1 и сульфитоксидаза, что, однако, не подтверждено другими исследованиями. M8 - чувствительный к трипсину антиген наружной митохондриальной мембраны. Анти-М8 можно найти только в сочетании с анти-М2 (но не всегда наоборот), и это сочетание является плохим прогностическим признаком. М9 - гликогенфосфорилаза - расположена во внешней мембране, ее структура также не подтверждена. Этот антиген был открыт случайно в митохондриальных фракциях печени крысы, очищенных от анти-М2. Он может быть обнаружен у пациентов с М2отрицательным ранним или бессимптомным ПБХ и связан с медленной прогрессией [14].

Уровни АMА не зависят от прогрессирования заболевания и/или терапии. По данным некоторых исследований, они обнаруживались через 11 лет после трансплантации печени почти у 100\% больных. AMA содержат иммуноглобулины типа A, M и G. Количество связанных с AMA CD8+ и CD4+ T-клеток в печени увеличивается более чем в 10 и 100 раз соответственно, в сравнении с их уровнем в периферической крови. AMA IgA можно найти в сыворотке, слюне или желчи и в сочетании с AMA IgG3 они указывают на прогрессирующую стадию заболевания и неблагоприятный прогноз [15]. АMА сопровождают острую печеночную недостаточность, но быстро исчезают по мере восстановления состояния [16].

Нарушение апоптоза считается триггером ПБХ, а именно, лишенная воздействия каспаз экспозиция антигена PDC-E2 холангиоцитами. Кроме того, неполный апоптоз эпителиоцитов желчных протоков, перенаправленный в некроз, приводил к патогенному воздействию внутриклеточных компонентов с последующей генерацией AMA [17]. АМА-отрицательные пациенты не отличаются от AMA-позитивных пациентов с точки зрения клинических или лабораторных проявлений. Что может быть частично объяснено несовершенством диагностических тестов, подтвержденным тем фактом, что по мере внедрения более усовершенствованных серологических тестов все больше АМА-негативных пациентов становятся АMAпозитивными [18,19]

\section{Антинуклеарные антитела.}

У почти 50\% пациентов с ПБХ в сыворотке обнаруживаются антинуклеарные антитела (АНА), образующие на ИФА свечение двух видов:

1. Множественные ядерные точки (multiple nuclear dots - MND) или ядерные тела (nuclear bodies - NB) - в результате связывания с антигенами внутри ядра.

2. Циркулярный ободок вокруг ядра (rim pattern) - в результате связывания с протеинами ядерных пор (в ядерной оболочке).

Картина множественных ядерных точек (multiple nuclear dots - MND) или нуклеарных тел (nuclear bodies - NB) характеризуется иммуноморфологическим окрашиванием 3-20 точек различного размера, также известных как ядерные тела или ядерные домены, распределенных по всему ядру клетки, за исключением ядрышек [20]. Основной антигенной мишенью реактивности ядерных точек является протеин с массой 53 кДа, называемый Sp100, состоящий из ядерного белка, содержащим 480 аминокислот с транскрипционной стимулирующей активностью. Анти-Sp100 антитела были описаны при ПБХ, больше у АМА-негативных пациентов и реже - при ревматологических заболеваниях. Обнаружение антител против Sp100 у пациентов с ПБХ связывают с неблагоприятным течением заболевания [21]. Помимо Sp100, еще один ядерный белок, называемый PML (promyelocytic leucemia factor - фактор промиелоцитарного лейкоза ПМЛ), был идентифицирован как дополнительная мишень антител к ядерным точкам сывороток пациентов с ПБХ. ПМЛ локализуется со Sp100 в структурах ядерных точек и экспрессируется в большом количестве в промиелоцитарных лейкобластах [22]. Показано, что Sp100 и PML являются коиммуногенными у пациентов с РBC, поскольку антиSp100 и анти-PML обычно сосуществуют в одной и той же сыворотке [23]. Высокая температура, тяжелые металлы и стресс вызывают обратимую фрагментацию тел PML, тогда как многие аутоиммунные и раковые заболевания увеличивают их количество. При вирусных инфекциях вирусные геномы накапливаются на периферии или в центре ядерных точек Анти-sp100-антитела обнаруживаются у приблизительно 20-30\% пациентов с ПБХ и при отсутствии других заболеваний могут подтвердить ПБХ [24]. Они являются очень специфическим маркером ПБХ, но также обнаруживаются при СКВ и прогрессирующем системном склерозе. Тестирование на наличие ядерных тел/Sp100 полезно для диагностики ПБХ, но только при наличии соответствующего клинического контекста. Другие болезни также не могут быть исключены, в первую очередь СКВ [25].

Sp140 - недавно обнаруженный компонент ядерных тел, идентифицированный с применением сыворотки пациентов ПБХ. Антитела против Sp140 обнаруживаются у 15\% пациентов с РВС в сочетании с анти-Sp100 и анти-ПМЛ и без связи с их клиническими или лабораторными признаками. Наличие анти-Sp140 не связано с определенной клинической картиной при ПБХ. Очень частое сосуществование антител против Sp140, Sp100 и ПМЛ свидетельствует о том, что ядерные тела являются полиантигенным комплексом при ПБХ и повышает диагностическую значимость этих реакций, которые особенно полезны в случае АMАнегативных случаев [26].

\section{Ядерный ободок или циркулярные ядерные} антитела.

В 1985 году у больных ПБХ были обнаружены антитела в виде перинуклеарного кольцевидного свечения. Их мишенью являются ядерные поры - массивные белковые комплексы в двуслойной ядерной оболочке эукариотических клеток. Они образуют шлюз, регулирующий поток макромолекул из ядра в цитоплазму (РНК и рибосомные белки) и наоборот из цитоплазмы в ядро (ДНК-полимераза, ламины, углеводы, сигнальные молекулы и липиды). Каждая ядерная пора содержит не менее 456 отдельных белковых молекул, состоящих из 30 нуклеопоринов, организованных в виде восьмиугольной симметричной цилиндрической структуры вокруг оси переноса и плоской псевдосимметрии через ядерную оболочку. Диаметр канала 
составляет примерно 5,2 нанометра у человека с глубиной примерно 45 нм. В ядерной оболочке клетки позвоночных в среднем около 2000 ядерных пор в зависимости от типа клетки и жизненного цикла, каждая из которых способна проводить 1000 транслокаций в секунду. В то время как более мелкие молекулы диффундируют через поры, более крупные молекулы могут распознаваться по специфическим сигнальным последовательностям, а затем распространяться c помощью нуклеопоринов в ядро. Нуклеопоринопосредованный транспорт напрямую не требует энергии, но зависит от градиента концентраций. Каждая из восьми белковых субъединиц, окружающих фактическую пору (внешнее кольцо), проецирует белок в форме спицы по каналу пор. Центр поры часто содержит пробкообразную структуру [27]. Важным регулятором трафика в эукариотических ядерных порах является гликопротеин-210 (нуклеопорин gp210). Он связывает ядерные поры с ядерной мембраной, главным образом внутри просвета поры двухслойной мембраны. Существует три домена, образующих его структуру: длинная люминальная цепь, основное полипептидное звено, ответственное за связь с ядерной мембраной, и карбоксильная цепь, ориентированная на цитоплазменную сторону мембраны. Сывороточные антиgp210 обнаруживаются у 10-40\% (25\%) пациентов с АМА+ и до 50\% AMА-негативных больных, в основном против 15-аминокислотной цепи цитоплазменной карбоксильной цепи. Эти высокоспецифичные антитела к ПБХ связаны с поздней стадией заболевания и высокой смертностью, что делает их надежным маркером быстрого прогрессирования к печеночной недостаточности на конечной стадии [28].

Анти-р62 антитела(Anti-p62) были обнаружены в 1987 году, также в виде перинуклеарного иммунофлюоресентного свечения. Аутоантигеном является нуклеопорин с массой 62 кДа, содержащий 520 аминокислот с высоким уровнем серина / треонина и связанный с ламинарной фракцией ядерного пористого комплекса. Р62 входит в комплекс из 3 составных протеинов: p60, p54 и p45, образуя комплекс p62 с массой 235 кДа. Комплекс р62 локализуется как на нуклеоплазматической, так и на цитоплазматической сторонах ядерных пор, а относительный диаметр комплекса p62 по сравнению с ядерным пористым комплексом предполагает, что он входит в структуру пор. Р62 также взаимодействует с белком ядерного транспорта (NTF2), который участвует в траффике белков между цитоплазмой и ядром [69]. Антитела к р62 составляют на 97\% специфичны к ПБХ, их можно обнаружить у 30-55\% пациентов, чаще в IV стадии, что является прогностическим маркером тяжести заболевания [29].

Антитела к ядерной оболочке (анти-Ламин и антиЛамин Б).

Ламины относятся кядерной пластине, которая является частью ядерной оболочки (наряду с внешней и внутренней мембраной, перинуклеарным пространством, соединенным с эндоплазматическим ретикулумом и ядерными порами, где соединяются внутренняя и внешняя мембраны). Белки ламин участвуют в расположении ядерных пор, разборке и реформировании ядерной оболочки, сохранении формы ядра во время митоза и запрограммированной гибели клеток. Они также играют косвенную роль в прикреплении ядра к эндоплазматической сети, поддерживая единую целостность внутриклеточных структур. Это достигается с помощью ламин и ламин-взаимодействующих белков (SUN1/ SUN2), соединяющихся с белками на внешней ядерной мембране. Эти белки, в свою очередь, взаимодействуют с элементами цитоскелета эндоплазматического ретикулума, образуя сильный комплекс, способный противостоять механическому стрессу. Ламины являются критическими мишенями для процесса апоптоза из-за их тесной связи с хроматином и ядерной оболочкой. Апоптотические каспазы атакуют ламины и расщепляют как А-, так и В-типы. Это позволяет хроматину отделяться от ядерной пластинки для конденсации. По мере продолжения апоптоза клеточные структуры медленно сжимаются в отдельные пузырьки. Наконец, эти апоптотические тела перевариваются фагоцитами [30].

Непрямая иммунофлюорусценция выявляет три типа антиламинарных антител в соответствии с типами ламин - А, В и С, обнаруженными у 6-8\% пациентов с ПБХ. Один из внутренних белков ядерной мембраны, рецептор ламин В, с терминальным доменом из 208 аминокислот, является мишенью для анти-LBR-антител, обнаруженных у 2-6\% пациентов с РВС, высокоспецифичных для этого заболевания с еще не оцененным клиническим значением [31].

\section{Антицентромерные антитела (АЦА).}

Центромер - это специализированная последовательность ДНК хромосомы, которая связывает пару сестринских хроматид (диаду). Во время митоза веретенообразные волокна прикрепляются к центромеру через кинетохоры - дискообразные белковые структуры в центре хроматиды, связывающий хромосому с микротрубочными полимерами из митотического веретена во время митоза и мейоза. Кинетохоры начинают, контролируют и руководят поразительными движениями хромосом во время деления клеток. Во время митоза, который возникает после дублирования хромосом во время фазы $\mathrm{S}$, две сестринские хроматиды удерживаются вместе, каждый со своим собственным кинетохором, который выступает в противоположных направлениях и прикрепляется к противоположным полюсам митотического веретена. После перехода от метафазы к анафазе сестринские хроматиды отделены друг от друга, а отдельные кинетохоры на каждой хроматиде приводят их движение к полюсам веретена, которые будут определять две новые дочерние клетки. Таким образом, кинетохор необходим для сегрегации хромосом, которая классически ассоциируется с митозом и мейозом. Даже самые простые кинетохоры состоят из более чем 19 различных белков [32, 33].

Антицентромерные антитела (АЦА) являются аутоантителами, специфичными к центромерам и кинетохорам. АЦА не являются специфичными и могут быть обнаружены у 10-30\% пациентов с ПБХ. В то время как пациенты с анти-gp210 прогрессируют до конечной стадии печеночной недостаточности, у пациентов с антицентромерными антителами часто развивается портальная гипертензия, что указывает на определенную роль АЦА в ПБХ. АЦА предсказывают развитие портальной гипертензии. Таким образом, анти-NPC и АЦА помогают в стратификации риска у бессимптомных пациентов с неблагоприятным исходом заболевания, что требует ранней терапии [34].

Диагностика. Согласно рекомендациям EASL 2017, повышенная щелочная фосфатаза печени в течение минимум 6 месяцев в сочетании с АМА в титре выше 1:40 достаточно для диагностики ПБХ. Характерная гистологическая картина разрушения желчных протоков 
позволяет подтвердить диагноз. Наличие АМА у здоровых людей может быть надежным предиктором развития в будущем ПБХ, даже если печеночные тесты являются нормальными. Гистологические данные печени у таких пациентов совместимы с диагностическими критериями ПБХ и требуют своевременной терапии УДХК, что позволяет замедлить болезнь задолго до того, как она проявится клинически и биохимически. Нет никакой корреляции между титром антител и тяжестью заболевания. Однако тип АМА, идентифицированный с помощью ИФА или теста фиксации комплимента (ТФК), теоретически позволяет прогнозировать неблагоприятное течение заболевания [35-37]. В трех исследованиях, включавших от 76 до 200 пациентов с ПБХ находившихся под наблюдением 6-18 лет, пациенты, у которых было обнаружено сочетание анти-М2, анти-М4 и/или анти-М8, выявленные по ИФА и ТФК, переходили на более тяжелые стадии болезни как клинически, так и биохимически, с такими исходами как смерть, трансплантация печени, портальная гипертензия с повышенными ЩФ, ГГТП, билирубином и $\mathrm{IgG}$. Тогда как группа с анти-М9 и анти-М2 вместе или по отдельности оставалась стабильной в доброкачественном течении заболевания. Однако, как бы ни был привлекателен этот подход, его применение в обычных лабораториях сильно ограничено вследствие потребности в свежих митохондриях для обнаружения этих антигенов с помощью ТФК или ИФА. Кроме того, этот вывод не был подтвержден в другом исследовании, который не выявил существенной корреляции между профилем АMA и конечным результатом у 472 пациентов [39]. Таким образом, наряду с холестатическими печеночными тестами анти-М2 AMA являются наиболее точными маркерами, что позволяет диагностировать ПБХ с уверенностью у 95\% пациентов. ИФА тест, основанный на PDC-E2/E3ВР, чувствителен к 93\% и на 96\% специфичен в диагностике ПБХ, но непрактичен из-за потребности в тканевых дериватах. ИФА с использованием рекомбинантного антигена, хотя и менее чувствительный, является более выполнимым и достаточным для обнаружения АМА в большинстве случаев. Анализ непрямой иммунофлюоресценции на анти-М2 АМА, золотой стандарт серодиагностики при ПБХ из-за его специфичности (почти 100\%) и чувствительности, является громоздким и очень зависит от компетентности специалиста, однако его следует использовать в небольшом проценте пациентов с ложноотрицательными результатами теста ELISA и клинически подтвержденным ПБХ Двойной $\mathrm{IgG} / \mathrm{IgA}$ ИФА тест, определяющий три основных митохондриальных и ядерных (gp210 и sp100) антигена, является тестом первой линии в диагностике ПБХ, в том числе у пациентов, классифицированных как негативные с помощью традиционных методов [40].

\section{Заключение}

Смоментаобнаруженияпервыхантимитохондриальных антител и их роли в патогенезе ПБХ в 1958г., открыто более 60 различных антител к компонентам клеточных структур, включая митохондриальные и ядерные мембраны. Появление усовершенствованных диагностических тестов позволило выявить новые антитела, а внедрение в лабораторную практику ИФА привело к заметному прогрессу в серодиагностике ПБХ, позволившим перевести 90\% АМА-отрицательных случаев в АМА-позитивные. Несмотря на противоречивые данные по поводу корреляции аутоантител с прогнозом ПБХ, ИФА с рекомбинантным антигеном является в настоящий момент стандартным тестом для диагностики ПБХ, и, наряду с показателями цитолиза, холестаза и гистологическими данными, подтверждает ПБХ у более чем 90\% больных.

Disclosures: There is no conflict of interest for all authors.

\section{Литература}

1. Jepsen PA,, Grønbæk LA, Vilstrup. Worldwide Incidence of Autoimmune Liver Disease. Digestive Diseases. 2015; 33: 2-12. https:// doi.org/10.1159/000440705

2. Zukowski TH, Jorgensen RA, Dickson ER, Lindor KD. Autoimmune conditions associated with primary biliary cirrhosis: response to ursodeoxycholic acid therapy. Am J Gastroenterol. 1998; 93(6):958-61. https://doi.org/10.1111/j.1572-0241.1998.00287.x

3. Wang L, Zhang FC, Zhang X. Therapeutic advances for primary biliary cholangitis: the old and the new. European Journal of Gastroenterology \& Hepatology. 2016; 28(6):615-621. https://doi.org/10.1097/MEG.0000000000000591

4. Scheenstra R, Peeters PM, Verkade HJ, Gouw AS. Graft fibrosis after pediatric liver transplantation: ten years of follow-up. Hepatology. 2009; 49:880-886. https://doi.org/10.1002/hep.22686

5. Yamagiwa S, Kamimura H, Takamura M, Aoyagi Y. Autoantibodies in primary biliary cirrhosis: Recent progress in research on the pathogenetic and clinical significance. World J Gastroenterol. 2014; 20(10): 2606-2612. https://doi.org/10.3748/wjg.v20.i10.2606

6. Hu CJ, Zhang FC, Li YZ, Zhang X. Primary biliary cirrhosis: What do autoantibodies tell us. World Journal of Gastroenterology. 2010; 16(29):3616-3629. https://doi.org/10.3748/wjg.v16.i29.3616

7. Tanaka A, Nezu S, Uegaki S, Mikami M, Okuyama S, Kawamura N et al. The clinical significance of IgA antimitochondrial antibodies in sera and saliva in primary biliary cirrhosis. Ann N Y Acad Sci. 2007; 1107:259-270. https://doi.org/10.1196/annals.1381.028

8. Siekevitz P. Powerhouse of the cell. Scientific American. 197(1):131-140. https://doi.org/10.1038/scientificamerican0757-131

9. Andersson SG, Karlberg O, Canbäck B, Kurland CG. On the origin of mitochondria: a genomics perspective. Philosophical Transactions of the Royal Society of London. Series B, Biological Sciences. 358 (1429): 165-177; 177-179. https://doi.org/10.1098/rstb.2002.1193

10. Chipuk JE, Bouchier-Hayes L, Green DR. Mitochondrial outer membrane permeabilization during apoptosis: the innocent bystander scenario. Cell Death and Differentiation. 2006; 13(8):1396-402. doi:10.1038/sj.cdd.4401963. PMID 16710362.https://doi.org/10.1038/ sj.cdd. 4401963

11. Berg CP, Stein GM, Klein R, Pascu M, Berg T, Kammer W,et al. Demonstration of PDC-E1 subunits as major antigens in the complement-fixing fraction M4 and re-evaluation of PDC-E1-specific antibodies in PBC patients. Liver Int. 2006; 26:846-855. https:// doi.org/10.1111/j.1478-3231.2006.01303.x

12. Nishio A1, Coppel R, Ishibashi H, Gershwin ME. The pyruvate dehydrogenase complex as a target autoantigen in primary biliary cirrhosis. Baillieres Best Pract Res Clin Gastroenterol. 2000;14(4):535-47. https://doi.org/10.1053/bega.2000.0102

13. Muratori L, Granito A, Muratori P, Pappas G, Bianchi F. Antimitochondrial Antibodies and OtherAntibodies in Primary Biliary Cirrhosis: Diagnostic and Prognostic Value. Clin Liver Dis. 2008; 12:261-276. https://doi.org/10.1016/j.cld.2008.02.009 
14. Preuss B, Berg C, Altenberend F, Gregor M, Stevanovic S, Klein R. Demonstration of autoantibodies to recombinant human sulphite oxidase in patients with chronic liver disorders and analysis of their clinical relevance. Clin Exp Immunol. 2007; 150:312-321. https:// doi.org/10.1111/j.1365-2249.2007.03482.x

15. Mutimer DJ, Fussey SP, Yeaman SJ, et al. Frequency of IgG and IgM autoantibodies to four specific M2 mitochondrial autoantigens in primary biliary cirrhosis. Hepatology. 1989; 10:403-7. https://doi.org/10.1002/hep.1840100402

16. Zhang FK, Jia JD, Wang BE. Clinical evaluation of serum antimitochondrial antibody-negative primary biliary cirrhosis. Hepatobiliary Pancreat Dis Int. 2004; 3:288-291.

17. Berg CP, Stein GM, Keppeler H, Gregor M, Wesselborg S, Lauber K. Apoptosis-associated antigens recognized by autoantibodies in patients with the autoimmune liver disease primary biliary cirrhosis. Apoptosis. 2008; 13:63-75. https://doi.org/10.1007/s10495-0070157-6

18. Hirschfield GM, Heathcote EJ. Antimitochondrial antibody-negative primary biliary cirrhosis. Clin Liver Dis. 2008; 12:323-331; viiiix. https://doi.org/10.1016/j.cld.2008.02.003

19. Liu B, Shi XH, Zhang FC, Zhang W, Gao LX. Antimitochondrial antibody-negative primary biliary cirrhosis: a subset of primary biliary cirrhosis. Liver Int. 2008; 28:233-239. https://doi.org/10.1111/j.1478-3231.2007.01651.x

20. Fusconi M, Cassani F, Govoni M, et al. Anti-nuclear antibodies of primary biliary cirrhosis recognize 78-92-kD and 96-100-kD proteins of nuclear bodies. Clin Exp Immunol. 1991; 83:291-7. https://doi.org/10.1111/j.1365-2249.1991.tb05630.x

21. Wichmann I, Montes-Cano MA, Respaldiza N, Alvarez A, Walter K, Franco E, et al. Clinical significance of anti-multiple nuclear dots/ Sp100 autoantibodies. Scand J Gastroenterol. 2003; 38:996-999. https://doi.org/10.1080/00365520310004876

22. Zuchner D, Sternsdorf T, Szostecki C, Heathcote EJ, Cauch-Dudek K, Will H. Prevalence, kinetics, and therapeutic modulation of autoantibodies against $\mathrm{Sp} 100$ and promyelocytic leukemia protein in a large cohort of patients with primary biliary cirrhosis. Hepatology. 1997; 26:1123-30. https://doi.org/10.1002/hep.510260506

23. Sternsdorf T, Guldner HH, Szostecki C, Grotzinger T, Will H. Two nuclear dot-associated proteins, PML and Sp100, are often coautoimmunogenic in patients with primary biliary cirrhosis. ScandJImmunol. 1995;42:257-68. https://doi.org/10.1111/j.1365-3083.1995. tb03652.x

24. Szostecki C, Guldner HH, Will H. Autoantibodies against 'nuclear dots' in primary biliary cirrhosis. Semin Liver Dis. 1997; 17:71-8. https://doi.org/10.1055/s-2007-1007184

25. Muratori P, Muratori L, Cassani F, Terlizzi P, Lenzi M, Rodrigo L, et al. Anti-multiple nuclear dots (anti-MND) and anti-SP100 antibodies in hepatic and rheumatological disorders. Clin Exp Immunol. 2002; 127(1): 172-175. https://doi.org/10.1046/j.1365-2249.2002.01719.x

26. Granito A., Wei-Hong Y., Muratori L., Lim M, Nakajima A., Ferri S.,et al. PML Nuclear Body Component Sp140 Is a Novel Autoantigen in Primary Biliary Cirrhosis. The American Journal of Gastroenterology. 2010; 105:125-131. https://doi.org/10.1038/ajg.2009.596

27. Nakamura M, Takii Y, Ito M, Komori A, Yokoyama T, Shimizu-Yoshida Y, et al. Increased expression of nuclear envelope gp210 antigen in small bile ducts in primary biliary cirrhosis. J Autoimmun. 2006; 26:138-145. https://doi.org/10.1016/j.jaut.2005.10.007

28. Nakamura M, Komori A, Ito M, Kondo H, Aiba Y, Migita K, et al. Predictive role of anti-gp210 and anticentromere antibodies in longterm outcome of primary biliary cirrhosis. Hepatol Res. 2007; 37(3): S412-S419. https://doi.org/10.1111/j.1872-034X.2007.00244.X

29. Bauer A1, Habior A2. Detection of Autoantibodies Against Nucleoporin p62 in Sera of Patients With Primary Biliary Cholangitis. Ann Lab Med. 2019; 39(3):291-298. https://doi.org/10.3343/alm.2019.39.3.291

30. Dittmer, Travis A; Misteli, Tom. The lamin protein family. Genome Biology. 2011; 12(5):222. https://doi.org/10.1186/gb-2011-12-5222

31. Gruenbaum Y, Wilson K; Harel A; Goldberg M; Cohen M. Review: Nuclear Lamins-Structural Proteins with Fundamental Functions. Journal of Structural Biology. 2000; 129(2):313-323. https://doi.org/10.1006/jsbi.2000.4216

32. Alberts B, Bray D., Hopkin K., Johnson A., Lewis J., Raff M., et al. Essential Cell Biology. New York: Garland Science. $2014 ; 4$.

33. Cheeseman I. The Kinetochore. Cold Spring Harb Perspect Biol. 2014; 6(7): a015826. https://doi.org/10.1101/cshperspect.a015826

34. Nakamura M, Kondo H, Mori T, Komori A, Matsuyama M, Ito M, et al. Anti-gp210 and anti-centromere antibodies are different risk factors for the progression of primary biliary cirrhosis. Hepatology. 2007; 45:118-127. https://doi.org/10.1002/hep.21472

35. Gao L, Tian X, Liu B, Zhang F. The value of antinuclear antibodies in primary biliary cirrhosis. Clin Exp Med. 2008; 8:9-15. https:// doi.org/10.1007/s10238-008-0150-6

36. Muratori P, Muratori L, Ferrari R, Cassani F, Bianchi G, Lenzi M, et al. Characterization and clinical impact of antinuclear antibodies in primary biliary cirrhosis. Am J Gastroenterol. 2003; 98:431-437. https://doi.org/10.1111/j.1572-0241.2003.07257.x

37. Invernizzi P, Podda M, Battezzati PM, Crosignani A, Zuin M, Hitchman E, et al. Autoantibodies against nuclear pore complexes are associated with more active and severe liver disease in primary biliary cirrhosis. J Hepatol. 2001; 34:366-372. https://doi.org/10.1016/ S0168-8278(00)00040-4

38. Klein R, Pointner H, Zilly W, Glässner-Bittner B, Breuer N, Garbe W, et al. Antimitochondrial antibody profiles in primary biliary cirrhosis distinguish at early stages between a benign and a progressive course: a prospective study on 200 patients followed for 10 years. Liver. 1997; 17(3):119-128. https://doi.org/10.1111/j.1600-0676.1997.tb00793.x

39. Joshi S, Cauch-Dudek K, Heathcote EJ, Lindor K, Jorgensen R, Klein R. Antimitochondrial antibody profiles: are they valid prognostic indicators in primary biliary cirrhosis? Am J Gastroenterol. 2002; 97(4):999-1002. https://doi.org/10.1111/j.1572-0241.2002.05620.x

40. Dähnrich C, Pares A, Caballeria L, Rosemann A, Schlumberger W, Probst C, et al. New ELISA for detecting primary biliary cirrhosisspecific antimitochondrial antibodies. Clin Chem. 2009; 55(5):978-85. https://doi.org/10.1373/clinchem.2008.118299

How to cite this article: Dana Saipiyeva, Manarbek Askarov, Turlybek Tuganbekov, Kulsara Rustemova, Vladimir Grigorevsky, Gulmira Dossatayeva, Nina Tostanovskaya. Antimitochindrial and antinuclear antibodies in primary biliary cholangitis [in Russian]. J Clin Med Kaz. 2019; 2(52):16-22 